Original article

\title{
GENES EXPRESSION PROFILES IN THE LOIN MUSCLE OF MANYCH MERINO SHEEP WITH DIFFERENT LIVE WEIGHT
}

\author{
V. TRUKHACHEV ${ }^{1}$, V. BELYAEV ${ }^{1}$, A. KVOCHKO ${ }^{1}$, A. KULICHENKO ${ }^{2}$, \\ D. KOVALEV ${ }^{2}$, S. PISARENKO ${ }^{2}$, A. VOLYNKINA ${ }^{2}$, M. SELIONOVA ${ }^{3}$, \\ M. AYBAZOV ${ }^{3}$, S. SHUMAENKO ${ }^{3}$, A. OMAROV ${ }^{3}$, T. MAMONTOVA, \\ N. GOLOVANOVA ${ }^{1}, O$. YATSYK ${ }^{1} \&$ A. KRIVORUCHKO ${ }^{1}$
}

${ }^{1}$ Faculty of Veterinary Medicine, Stavropol State Agrarian University, Stavropol, Russian Federation; ${ }^{2}$ Stavropol Research Anti-plague Institute, Stavropol, Russian Federation; ${ }^{3}$ All-Russian Research Institute of Sheep and Goat Breeding; Stavropol, Russian Federation

\section{Summary}

Trukhachev, V., V. Belyaev, A. Kvochko, A. Kulichenko, D. Kovalev, S. Pisarenko, A. Volynkina, M. Selionova, M. Aybazov, S. Shumaenko, A. Omarov, T. Mamontova, N. Golovanova, O. Yatsyk \& A. Krivoruchko, 2016. Genes expression profiles in the loin muscle of Manych Merino sheep with different live weight. Bulg. J. Vet. Med., 19, No 1, 19-29.

\begin{abstract}
Genomic breeding methods of sheep require the identification of new genes that affect the quality of meat. Using technology of reverse transcription-quantitative real-time PCR (RT-qPCR) we investigated the expression of 48 genes in the loin muscle. Samples were collected from 19 rams (10 with high and 9 with low live weight) of Manych Merino sheep breed, bred in Russia. The genes GAPDH, PYGM, CAPN3, CAST, ATP5G1, CALM2, SOD1, ASIP and VEGFA showed the highest expression. The group of genes with a medium level of expression included ATOX1, CAPN1, GHR, IGF2, SS18L2, YWHAZ, MYOD1, FOS, CAPN2, GGTA2P, SLC2A3, C-MET, ACVR2A, DGAT1, TLR6, IGF1, ABCG2, FST, BEGAIN. Low levels of expression had genes PYGL, OXTR, BAMBI, PPARG2, SPP2, MSTN, CDKN1A, TGFB1, CYP2J, CXCR4, FGF5, LEPR, IGFBP4, GH, SERT, TSHR. Practical absence of expression was detected for the genes BMP15, FGF7, GDF9 and SST. A significant relationship between the expression level with the live weight of investigated animals was found for FGF5 and GH genes. As a result of the research we suggest investigated genes as new candidate genes, and the study of their structure will permit to use them as genetic markers in developing new breeds of sheep.
\end{abstract}

Key words: expression, gene, meat, musculus longissimus, PCR, sheep

\section{INTRODUCTION}

Nowadays, a number of genes, the structure of which is related to the parameters of meat productivity in sheep are known.
Most of them belong to the group of growth regulators of muscle fibres - the genes of myostatin, calpastatin, calpain, 
and others. Revealing individual alleles in their structure allows the identification of mutations associated with high meat quality in sheep. However, is not always possible to predict with sufficient accuracy the quality of productive animals only through evaluation of the structure of these genes which indicates the need to search for new candidate genes whose function is associated with the development of the muscle fibres in sheep (Moradi et al., 2012; Miao \& Luo, 2013).

The identification of genes that play important role in the growth of muscle tissue of sheep may be during the study of expression profiles by estimating the amount of mRNA of certain genes in muscles. The expression profile reflects the activity of the functioning of individual genes and characterises the synthetic processes in muscles, different in some sheep breeds. There are high chances that the changes in the structure of genes with high expression levels have a more significant impact on the growth and development of muscle tissue in sheep, as shown by Hamill et al. (2012) in pigs.

Using Affymetrix Bovine Expression Array technique, Fleming-Waddell et al. (2007) have found a particular gene expression profile in skeletal muscle in sheep with callipyge mutation. Studies of genes expression profiles in muscles of sheep are provided by Lobo et al. (2012), which revealed different expression of genes MyoD1 and IGFBP4, associated with the breed of sheep and their productive qualities. Zhang et al. (2013) conducted a study of gene expression in two sheep breeds by sequencing and revealed significant differences in more than 1,300 genes. Continued research has allowed them to describe 34 genes with different expression related to the development and differentiation of muscle cells (Zhang et al., 2014).

In the Russian Federation there are a number of sheep breeds, bred by local breeders and adapted to life in the steppes territory of the North Caucasus. One such breed is the Manych Merino, registered in 1993. Sheep of this breed are widely used in different climatic zones in all categories of farms. Their distinguishing features are the stable breeding qualities and high productivity in the arid steppe zone of the North Caucasus (Babichev \& Moroz, 1992; Surov \& Aboneev, 2009).

The study of the structure of genes related to meat productivity and evaluation of their expression in the muscle of the Russian sheep breeds was not carried out. In our study we used Dynamic Array Gene Expression technology by Fluidigm (USA) for reverse transcription-quantitative real-time PCR (RT-qPCR) to compare gene transcription profiles in the loin muscle (musculus longissimus) of Manych Merino sheep breed.

\section{MATERIALS AND METHODS}

\section{Animals and sample collection}

All work was provided in the Genetic Laboratory of Veterinary Care Center (Stavropol State Agrarian University, Russian Federation). We have investigated 19 Manych Merino rams $(n=19)$, one year of age, from a livestock breeding farm of Stavropol Krai, Russian Federation. All animals were healthy, were kept in optimal conditions and were fed a total mix ration. In order to obtain more significant data about variants of genes expression profiles we selected for the research 10 animals with maximum live weight, and 9 animals of the same population with a minimum live weight. After the slaughter, samples from the centre of loin 
muscles about $1 \times 1 \times 1 \mathrm{~cm}$ were transported to lab.

\section{$m R N A$ collection and $c D N A$ preparation}

RNA was isolated from a sample weight of $0.1 \mathrm{~g}$ by extraction with TRIzol Reagent («Life Technologies», USA) according to the manufacturer's protocol.

Reverse transcription was performed by using Reverse Transcription Master Mix Kit (Fluidigm, USA). To apply a set of preamplification PreAmp Master Mix and TaqMan Assays (Fluidigm, USA). For amplification was used T100 Thermal Cycler (BioRad, USA).

Quantitation of cDNA in samples was performed by using a fluorimeter Qubit 2.0 and reagents Qubit ds DNA HS Assay (Invitrogen, USA), a qualitative assessment of the cDNA was performed by using NanoDrop spectrophotometer 2000C (ThermoScientific, USA) at a value of A260/A280 equal to 1.8 .

Reverse transcription-quantitative realtime PCR (RT-qPCR).

Primers to 48 target genes (Table 1) were developed by Fluidigm, USA. To perform real-time PCR, 96.96 Dynamic Array Gene Expression (Fluidigm, USA) were used. Preparation array was performed on Fluidigm IFC Controller (Fluidigm, USA), for real-time PCR and accounting of results used Biomark HD System (Fluidigm, USA) with negative controls in accordance with the equipment manufacturer protocols and reagents. Analysis of gene expression was performed by using Fluidigm Real-Time PCR Analysis Software (Fluidigm, USA). The software provides amplification curves, colour-coded heat maps and cycle threshold $\left(\mathrm{C}_{\mathrm{t}}\right)$ data for each run. The default cutoff of 0.65 was the arbitrary value for taking $C_{t}$ into account.

\section{Statistical analysis}

For statistical analysis used Student's $t$ test in MS Excel for Windows statistical plug-in. Differences were considered statistically significant if $\mathrm{P}<0.05$.

\section{RESULTS}

In our study we evaluated the expression of 48 genes involved in the regulation of growth and development of cellular structures by the number of synthesised mRNA in loin muscle tissue of the Manych Merino sheep breed. Results of accounting RT-qPCR, represented by Fluidigm RealTime PCR Analysis Software in the form of individual expression profiles of studied genes are shown on Fig. 1.

Based on the analysis of digital data of the expression levels of the studied genes, they were divided into three groups: genes with a high level of expression $\left(\mathrm{C}_{t}\right.$ from 9 to 12), medium level of expression $\left(C_{t}\right.$ from 12 to 16$)$ and low level $\left(\mathrm{C}_{\mathrm{t}}\right.$ more than 16) (Tables 2-4).

The highest expression in loin muscle was that of the GAPDH gene. The smallest difference between the minimum and maximum value of $C_{t}$ among genes with high expression of the examined animals was found in the gene CAPN3, less than 2.5. The greatest difference in $C_{t}$ of some individuals was observed in genes CAST and ATP5G1, it was nearly 3.8 (Table 2).

Among the genes with medium level of expression (Table 3) the difference in the expression intensity (performance $C_{t}$ ) was the least for genes SS18L2, CAPN2, GGTA2P, ACVR2A and DGAT1. For these genes the difference between the minimum and the maximum $C_{t}$ value did not exceed 2. The greatest difference in terms of the expression of individual animals was identified in this group for genes IGF2, MYOD1, FOS, SLC2A3 
Genes expression profiles in the loin muscle of Manych Merino sheep with different live weight

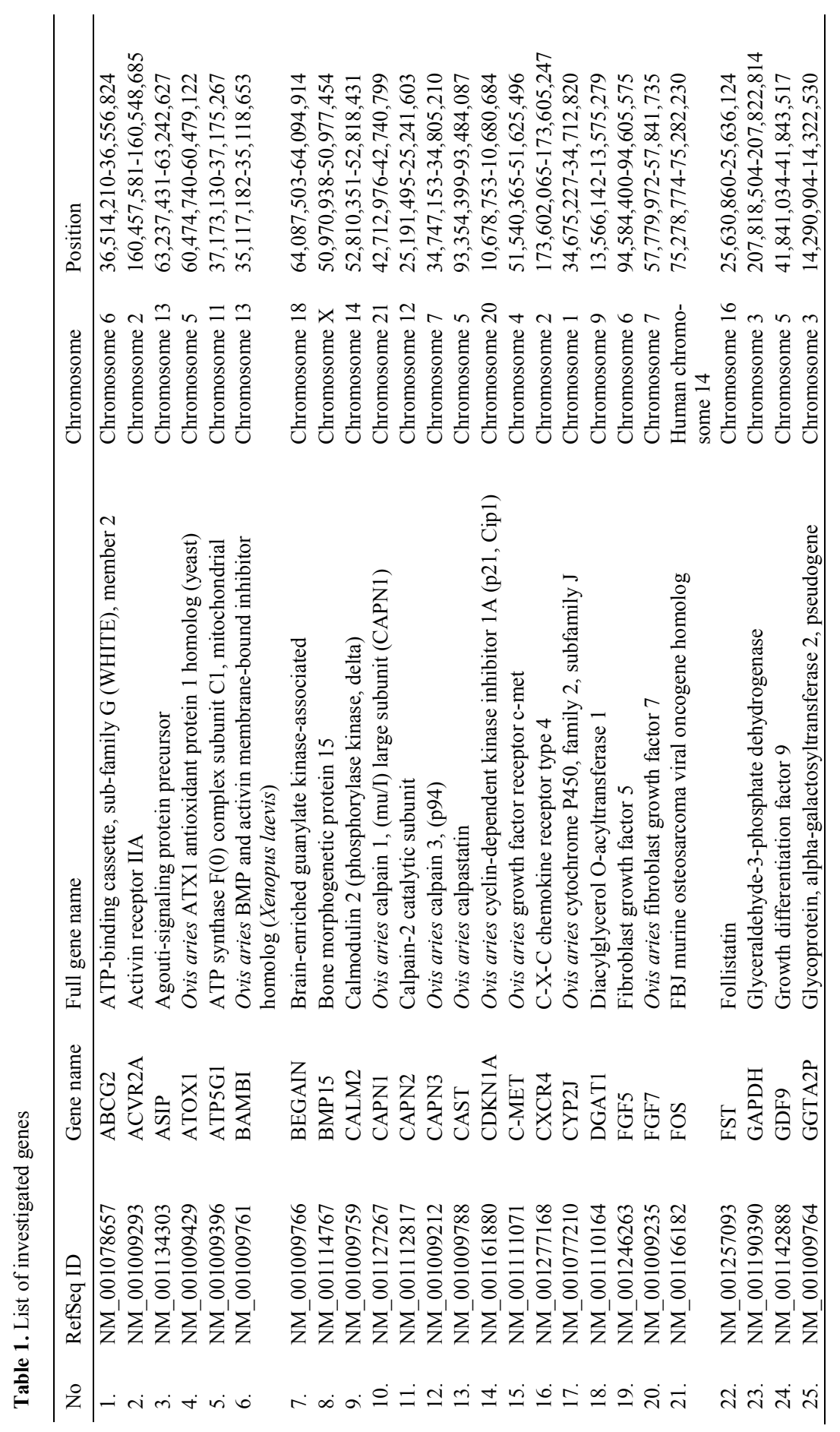


V. Trukhachev, V. Belyaev, A. Kvochko, A. Kulichenko, D. Kovalev, S. Pisarenko, A. Volynkina et al.

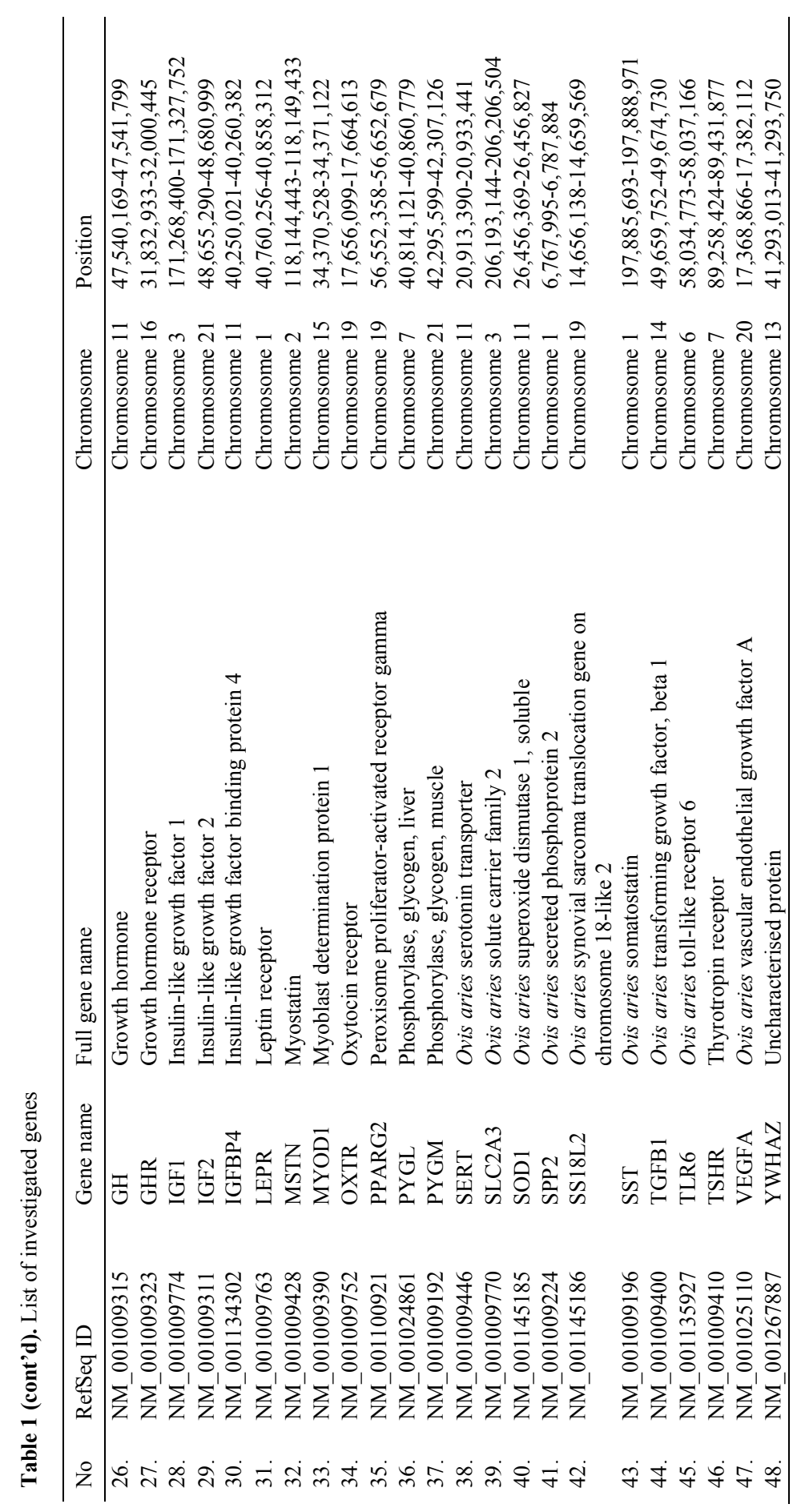

BJVM, 19, No 1 
and BEGAIN. The difference in $\mathrm{C}_{t}$ for these genes was more than 5.5, and for gene BEGAIN it was 8.3.

Analysis of the range of individual parameters values of gene expression in loin muscle among a group of genes with low expression levels (Table 4) showed that the difference between minimum and maximum $C_{t}$ was the lowest for the genes PYGL and PPARG2. In numerical terms, it was less than 2.7. For genes OXTR, BAMBI, SPP2, CXCR4, FGF5 and GH range size of $C_{t}$ was more than 6.5 , while for the $\mathrm{GH}$ gene it was the highest of all the studied genes in this group - 7.7.

To assess the connection of expression of individual genes with an integral indicator of productivity of sheep as live weight, animals were divided into two groups - with high and low weight. The average live weight was significantly different between groups at $6.32 \mathrm{~kg}$ $(\mathrm{P}<0.05)$.

The intensity of average expression of each of the two groups of animal genes was classified into three groups: with low expression or non-expressed (Table 4), with an average expression (Table 4) and with high expression (Table 2).

Genes BMP15, FGF7, GDF9 and SST in our study had the lowest, trace amounts of mRNA performance (maximum values $\mathrm{C}_{t}$ or no appearance of luminescence in probes), which allowed considering them practically non transcribed.

Genes LEPR, IGFBP4, GH, SERT and TSHR showed the lowest expression value in which $C_{t}$ was greater than 19 . Three genes - IGFBP4, GH and SERT are located on chromosome 11, the first and second occupied very similar loci.

Relatively low levels of expression were observed in gene MSTN, which is directly related to the regulation of the intensity of the muscle fibres growth.

Analysis of intensity of the individual genes expression related to the live weight showed that the two groups of examined animals were significantly different each from the other only by the intensity of the expression of two genes - FGF5 and GH. The intensity of FGF5 gene expression of

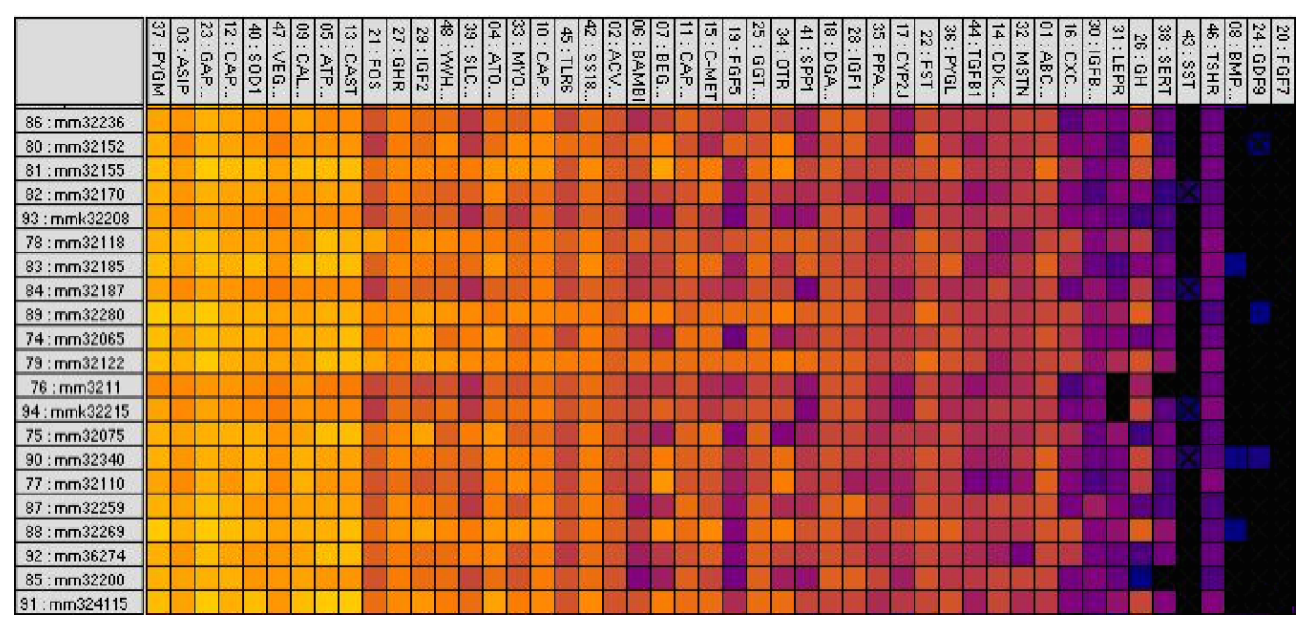

Fig. 1. Individual expression profiles of 19 ram Manych Merino breed. The heat map colours correspond to $C_{t}$ values: lighter cells indicate higher expression; a black square indicates no $C_{t}$ value or a value outside of the range. Left column: individual number of animal in farm documentation. 
V. Trukhachev, V. Belyaev, A. Kvochko, A. Kulichenko, D. Kovalev, S. Pisarenko, A. Volynkina et al.

Table 2. High-expression genes in the loin muscle of Manych Merino sheep with high $(61.25 \pm 0.64$ $\mathrm{kg})$ and low $(54.93 \pm 0.38 \mathrm{~kg})$ live weight. Data are presented as mean $\pm \mathrm{SEM}$

\begin{tabular}{lrcc}
\hline Gene name & $\mathrm{C}_{\mathrm{t}}$, High weight $(\mathrm{n}=10)$ & $\mathrm{C}_{\mathrm{t}}$, Low weight $(\mathrm{n}=9)$ & P value \\
\hline GAPDH & $9.42 \pm 0.28$ & $9.28 \pm 0.30$ & 0.73 \\
PYGM & $10.02 \pm 0.28$ & $9.75 \pm 0.29$ & 0.50 \\
CAPN3 & $10.33 \pm 0.22$ & $10.31 \pm 0.25$ & 0.95 \\
CAST & $10.33 \pm 0.43$ & $10.46 \pm 0.49$ & 0.83 \\
ATP5G1 & $10.35 \pm 0.43$ & $10.52 \pm 0.49$ & 0.79 \\
CALM2 & $10.43 \pm 0.19$ & $10.58 \pm 0.35$ & 0.70 \\
SOD1 & $10.56 \pm 0.28$ & $10.53 \pm 0.38$ & 0.95 \\
ASIP & $10.88 \pm 0.28$ & $11.06 \pm 0.36$ & 0.68 \\
VEGFA & $11.52 \pm 0.27$ & $11.60 \pm 0.27$ & 0.82 \\
\hline
\end{tabular}

animals with higher live weight was $14.5 \%$ higher than in animals with low weight. The same pattern was found for genes $\mathrm{GH}$, but the magnitude of the differences in this case was $21 \%$.

The expression of other genes with low content of mRNA in muscle was not significantly different between animals with different live weight.
The most intensively expressed genes in the loin muscle of Manych Merino sheep breed were GAPDH, PYGM, CAPN3, CAST and ATP5G1. The expression of these genes in more than 2 times than the level of gene expression TSHR, showed the lowest level of mRNA of transcribed genes in our study.

Table 3. Medium-expression genes in the loin muscle of Manych Merino sheep with high $(61.25 \pm$ $0.64 \mathrm{~kg})$ and low $(54.93 \pm 0.38 \mathrm{~kg})$ live weight. Data are presented as mean $\pm \mathrm{SEM}$.

\begin{tabular}{lccc}
\hline Gene name & $\mathrm{C}_{\mathrm{t}}$, High weight $(\mathrm{n}=10)$ & $\mathrm{C}_{\mathrm{t}}$, Low weight $(\mathrm{n}=9)$ & P value \\
\hline ATOX1 & $12.58 \pm 0.32$ & $12.68 \pm 0.39$ & 0.85 \\
CAPN1 & $12.66 \pm 0.17$ & $12.64 \pm 0.28$ & 0.95 \\
GHR & $12.70 \pm 0.28$ & $12.63 \pm 0.23$ & 0.84 \\
IGF2 & $12.92 \pm 0.61$ & $12.81 \pm 0.44$ & 0.88 \\
SS18L2 & $13.10 \pm 0.16$ & $13.08 \pm 0.27$ & 0.96 \\
YWHAZ & $13.49 \pm 0.34$ & $13.04 \pm 0.38$ & 0.36 \\
MYOD1 & $13.91 \pm 0.40$ & $13.54 \pm 0.55$ & 0.57 \\
FOS & $14.29 \pm 0.57$ & $14.26 \pm 0.76$ & 0.97 \\
CAPN2 & $14.36 \pm 0.20$ & $14.32 \pm 0.20$ & 0.89 \\
GGTA2P & $14.60 \pm 0.28$ & $14.46 \pm 0.25$ & 0.69 \\
SLC2A3 & $14.70 \pm 0.67$ & $14.67 \pm 0.78$ & 0.97 \\
C-MET & $14.78 \pm 0.42$ & $14.99 \pm 0.56$ & 0.76 \\
ACVR2A & $14.82 \pm 0.16$ & $14.80 \pm 0.13$ & 0.89 \\
DGAT1 & $14.91 \pm 0.23$ & $14.94 \pm 0.15$ & 0.92 \\
TLR6 & $15.26 \pm 0.30$ & $14.90 \pm 0.43$ & 0.49 \\
IGF1 & $15.30 \pm 0.42$ & $15.08 \pm 0.36$ & 0.68 \\
ABCG2 & $15.36 \pm 0.24$ & $15.47 \pm 0.29$ & 0.76 \\
FST & $15.40 \pm 0.26$ & $15.03 \pm 0.35$ & 0.39 \\
BEGAIN & $15.48 \pm 0.85$ & $14.67 \pm 0.86$ & 0.49 \\
\hline
\end{tabular}


Genes expression profiles in the loin muscle of Manych Merino sheep with different live weight

Table 4. Low-expression genes in the loin muscle of Manych Merino sheep with high $(61.25 \pm 0.64$ $\mathrm{kg})$ and low $(54.93 \pm 0.38 \mathrm{~kg})$ live weight. Data are presented as mean $\pm \mathrm{SEM}$

\begin{tabular}{lccc}
\hline Gene name & $\mathrm{C}_{\mathrm{t}}$, High weight $(\mathrm{n}=10)$ & $\mathrm{C}_{\mathrm{t}}$, Low weight $(\mathrm{n}=9)$ & P value \\
\hline PYGL & $16.01 \pm 0.29$ & $16.09 \pm 0.34$ & 0.85 \\
OXTR & $16.02 \pm 0.76$ & $14.64 \pm 0.73$ & 0.18 \\
BAMBI & $16.63 \pm 0.56$ & $15.78 \pm 0.70$ & 0.33 \\
PPARG2 & $16.79 \pm 0.22$ & $16.86 \pm 0.24$ & 0.83 \\
SPP2 & $17.00 \pm 0.60$ & $16.77 \pm 0.84$ & 0.82 \\
MSTN & $17.15 \pm 0.46$ & $16.59 \pm 0.21$ & 0.26 \\
CDKN1A & $17.32 \pm 0.45$ & $16.95 \pm 0.35$ & 0.50 \\
TGFB1 & $17.43 \pm 0.45$ & $17.20 \pm 0.30$ & 0.66 \\
CYP2J & $17.44 \pm 0.36$ & $17.51 \pm 0.49$ & 0.91 \\
CXCR4 & $18.63 \pm 0.69$ & $18.69 \pm 0.77$ & 0.95 \\
FGF5 & $18.83 \pm 0.57$ & $16.45 \pm 0.77$ & 0.02 \\
LEPR & $19.88 \pm 0.41$ & $20.22 \pm 0.53$ & 0.60 \\
IGFBP4 & $20.00 \pm 0.39$ & $19.90 \pm 0.39$ & 0.85 \\
GH & $20.07 \pm 1.36$ & $16.61 \pm 0.81$ & 0.04 \\
SERT & $20.61 \pm 0.39$ & $21.56 \pm 0.57$ & 0.17 \\
TSHR & $22.57 \pm 0.89$ & $22.98 \pm 0.58$ & 0.68 \\
BMP15 & Not expressed & Not expressed & \\
FGF7 & Not expressed & Not expressed & \\
GDF9 & Not expressed & Not expressed & \\
SST & Not expressed & Not expressed & \\
\hline
\end{tabular}

\section{DISCUSSION}

The main task of the study was to evaluate the expression of genes in loin muscle, which is a reference in the definition of a number of parameters that characterise the quality of the sheep meat. Weakly expressed genes may have a different effect on the myocytes. If these are genes of energy metabolism enzymes, it is possible that their lower expression limits the development of muscle fibres. At the same time, for regulatory genes, low expression indices may be enough for a major impact on the size and structure of the muscle (Braun \& Gautel, 2011).

We also based our choice of the studied genes on known data for farm animals about their impact on the quality of meat (Kogelman et al., 2011), and the information of the impact on muscle growth in humans and laboratory animals (Braun \& Gautel, 2011; Garatachea \& Lucía, 2013).

Among selected gene expressions for the study there are a large number of encoding growth factors, activins, chemokines and their receptors - MSTN, VEGFA, TGFB1, FGF5, IGFBP4, FGF7, GDF9, IGF1, IGF2, MYOD1, C-MET, BMP15, PPARG2, BAMBI, CAPN1, CAPN2, CAPN3, CAST, ASIP, CXCR4, CDKN1A. We investigated the gene expression of a number of hormones and their receptors FST, TLR6, ACVR2A, GH, GHR, SST, TSHR, SERT, OXTR, CALM2, LEPR. To evaluate the effect of genes on the energy metabolism and the transport of substances we investigated the expression of PYGL, SPP2, CYP2J, ATOX1, GGTA2P, DGAT1, ABCG2, BEGAIN, SLC2A3, GAPDH, PYGM, ATP5G1, SOD1. 
Mutations in several of the investigated genes related to the growth and development of muscles in a number of pathological processes in humans and animals, which also points to the possibility of their use as candidate genes for assessing the quality of meat - FOS, YWHAZ, SS18L2.

For gene expression studying there are several methods: sequencing of cDNA, taken by reverse transcription (Wang et al., 2014; Zhang et al., 2014), estimating the number of cDNA by hybridisation on biochips (Lobo et al., 2012) and reverse transcription-quantitative real-time PCR (Sun et al., 2014). Thus, the latter method is the most accurate and is used to validate the results obtained with microarray hybridisation (Lobo et al., 2012). Therefore, to obtain the most accurate results, we used reverse transcription-quantitative real-time PCR on 96.96 Dynamic Array Gene Expression (Fluidigm, USA) in our study.

During the study of gene expression, we have assumed that the maximum intensity of the performance will be at the transcription of genes encoding proteins of energy metabolism and transport systems, and that was confirmed in the analysis of the results. Thus, the maximum expression in this study was found for the gene GAPDH. In their study, Zhu et al. (2015) investigated the variability of expression of GAPDH gene in musculus longissimus dorsi of goats. The authors obtained a value of standard deviation of the $C_{t}$ of about 0.77 , which differed little from the value in our research -0.84 .

The PYGM gene was expressed in the loin muscle with the almost same intensity as the GAPDH gene. Two genes, performing regulatory functions of muscle fibres - CAPN3 and CAST had $C_{t}$ value one unit less than GAPDH as it has been shown in several studies (Azari et al., 2012; Ranjbari et al., 2012). Since they belong to the gene regulatory peptides group, we expected lower rates of expression for them.

In general, in our opinion the group of genes with high expression, despite the absence of differences in the intensity of transcription between animals with different live weight is paramount in relation to the identification of molecular markers of sheep meat productivity. The magnitude of expression of individual value variation may be associated with the presence of allelic variants of genes with different functional activity. Focusing on this figure, we should pay attention in future studies to the structure of the gene ATP5G1, encoding ATP synthase - an enzyme with key position in energy metabolism. The variability of expression of this gene is identical to that of the gene of CAST, whose value for meat sheep productivity is proven.

Among the genes, which have shown in our study average results of the expression activity, the most noteworthy genes are IGF2, MYOD1, FOS, SLC2A3 and BEGAIN. Their high variability of expression may be a consequence of the presence of molecular changes, revealing that we will be able to obtain important markers for genomic selection. As can be seen, MYOD1 was among the genes coding myoblast determination protein 1 , directly related to the regulation of myocyte development.

In the group of genes with low expression, in our opinion, the genes OXTR, BAMBI, SPP2, CXCR4, FGF5 and GH deserve a special attention. Also, as in the groups with other expression levels, these genes have shown the maximum range of the individual variability of expression indices. And for the two genes - FGF5 
and $\mathrm{GH}$ we have found significant differences in expression between the groups with different levels of live weight. The possibility of growth hormone gene expression in muscle has already been proved for a number of animals (Moria \& Devlinb, 1999), and the first time we have confirmed it for the sheep.

In investigations of Jeanplong et al. (2015) the expression of the MSTN gene in the muscle tissue of sheep was higher than that of IGF1gene. According to our data, the IGF1 gene was expressed with less intensity than MSTN. These differences can be explained by the breed characteristics of animals, or the fact that the authors used semitendinosus muscle tissue for the analysis, whereas we used loin muscle, the activity of the genes transcription of which may be different.

Genes BMP15, FGF7, GDF9 and SST, the expression of which in loin muscle of sheep has not been identified, nevertheless cannot be excluded from the list of gene-candidates affecting the meat quality of sheep. It is possible that they may have a remote action by producing in other tissues. Besides, growth differentiation factor 9 (GDF9) belongs to the same group as the myostatin (MSTN, GDF8), which has a direct and proven impact on the growth and development of muscle tissue.

\section{CONCLUSION}

The study of expression of 48 genes in the loin muscle of Manych Merino breed rams has allowed to characterise the animals of this breed in terms of transcription of genes, associated with key regulating processes of muscle growth and performance of enzyme systems of energy metabolism. These data allow to understand the genetic aspects of the muscle fibres of sheep and of mammals in general. The expression of several genes in the muscles has been studied for the first time and the results will be used in further work on the genetics of animals and humans. The main result is the justification of the need for further study of the structure of the investigated genes and identification of their mutations associated with high levels of meat quality of sheep and other farm animals.

\section{ACKNOWLEDGMENTS}

This project was funded by Ministry of Agriculture of the Russian Federation (agreement on the procedure and conditions for granting subsidies to financial security, state order for the provision of public services (works) by December 30, 2013 № 3119/13).

\section{REFERENCES}

Azari, M. A., E. Dehnavi, S. Yousefi \& L. Shahmohamadi, 2012. Polymorphism of calpastatin, calpain and myostatin genes in native Dalagh sheep in Iran. Slovak Journal of Animal Science, 45, 1-6.

Babichev, D. V. \& V. A. Moroz, 1992. Wider use of sheep Manychsky type of the Stavropol breed. Sheep breeding, 2, 8-19.

Braun, T. \& M. Gautel, 2011. Transcriptional mechanisms regulating skeletal muscle differentiation, growth and homeostasis. $\mathrm{Na}$ ture Reviews Molecular Cell Biology, 12, 349-361.

Fleming-Waddell, J. N., L. M. Wilson, G. R. Olbricht, T. Vuocolo, K. Byrne, B. A. Craig, R. L. Tellam, N. E. Cockett \& C. A. Bidwell, 2007. Analysis of gene expression during the onset of muscle hypertrophy in callipyge lambs. Animal Genetics, 38, 28-36.

Garatachea, N. \& A. Lucía, 2013. Genes and the ageing muscle: A review on genetic association studies. Age, 35, 207-233. 
Hamill, M. R., J. McBryan, C. McGee, A. M. Mullen, T. Sweeney, T. Talbot, M. T. Cairns \& G. C. Davey, 2012. Functional analysis of muscle gene expression profiles associated with tenderness and intramuscular fat content in pork. Meat Science, $\mathbf{9 2}$, 440-450.

Jeanplong, F., C. C. Osepchook, S. J. Falconer, H. K. Smith, J. J. Bass, C. D. McMahon \& J. M. Oldham, 2015. Undernutrition regulates the expression of a novel splice variant of myostatin and insulin-like growth factor 1 in ovine skeletal muscle. Domestic Animal Endocrinology, 52, 17-24.

Kogelman, L. J. A., K. Byrne, T. Vuocolo, N. S. Watson-Haigh, H. N. Kadarmideen, J. W. Kijas, H. V. Oddy, G. E. Gardner, C. Gondro \& R. L. Tellam, 2011. Genetic architecture of gene expression in ovine skeletal muscle. BMC Genomics, 12, 607.

Lobo, A. M. B., S. E. F. Guimaraes, S. R. Paiva, F. F. Cardoso, F. F. Silva, G. A. J. Fernandes \& R. N. B. Lobo, 2012. Differentially transcribed genes in skeletal muscle of lambs. Livestock Science, 150, 3141.

Miao, X. \& Q. Luo, 2013. Genome-wide transcriptome analysis between small-tail Han sheep and the Surabaya fur sheep using high-throughput RNA sequencing. Reproduction, 6, 587-596.

Moradi, M. H., A. Nejati-Javaremi, M. Moradi-Shahrbabak, K. G. Dodds \& J. C. McEwan, 2012. Genomic scan of selective sweeps in thin and fat tail sheep breeds for identifying of candidate regions associated with fat deposition. BMC Genetics, 13, 10.

Moria, T. \& R. H. Devlinb, 1999. Transgene and host growth hormone gene expression in pituitary and nonpituitary tissues of normal and growth hormone transgenic salmon. Molecular and Cellular Endocrinology, 149, 129-139.

Ranjbari, M., A. Hashemi, K. Mardani \& R. Darvishzadeh, 2012. Allelic polymorphism of Makoei sheep calpastatin gene identified by polymerase chain reaction and sin- gle strand conformation polymorphism. Journal of Agricultural Science and Technology, 14, 533-538.

Sun, W., R. Su, D. Li, H. H. Musa, Y. Kong, J. T. Ding, Y. H. Ma, L. Chen, Y. F. Zhang \& W. Z. Wu, 2014. Developmental changes in IGF-I and MyoG gene expression and their association with meat traits in sheep. Genetics and Molecular Research, 13, 2772-2783.

Surov, A. I. \& V. V. Aboneev, 2009. On improvement of the Manych Merino sheep breed. Sheep, Goats, Wool Business, 3, 7-9.

Zhang, C., G. Wang, J. Wang, Z. Ji, Z. Liu, X. Pi \& C. Chen, 2013. Characterization and comparative analyses of muscle transcriptomes in Dorper and Small-tailed Han sheep using RNA-Seq technique. PLoS ONE, 8, 1-13.

Zhang, C., G. Wang, J. Wang, Z. Ji, F. Dong \& T. Chao, 2014. Analysis of differential gene expression and novel transcript units of ovine muscle transcriptomes. PLoS ONE, 9, 1-7.

Zhu, W., Y. Lin, H. Liao \& Y. Wang, 2015. Expression studies related to intramuscular fat deposition in Capra hircus skeletal muscle. PLOS ONE, 10, e0121280.

Wang, X., C. Zhou, X. Xu, R. Geng, J. Zhou, Y. Yang, Z. Yang \& Y. Chen, 2014. Transcriptome profile analysis of adipose tissues from fat and short-tailed sheep. Gene, 549, 252-257.

Paper received 18.05.2015; accepted for publication 15.06.2015

\section{Correspondence:}

Dr. Alexander Krivoruchko Faculty of Veterinary medicine Stavropol State Agrarian University Stavropol, Russian Federation 355017, Zootehnichesky, 12

Phone: +79188814327

Fax: +78652286738

e-mail: rcvm@yandex.ru 